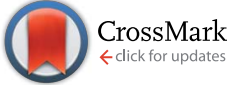

Cite this: Chem. Sci., 2016, 7, 6721

\title{
Self-powered fluorescence display devices based on a fast self-charging/recharging battery (Mg/ Prussian blue) $\uparrow$
}

\author{
Hui Zhang, ${ }^{\mathrm{ab}}$ You Yu, ${ }^{\mathrm{ab}}$ Lingling Zhang, ${ }^{\mathrm{ab}}$ Yiwen Zhai ${ }^{\mathrm{ab}}$ and Shaojun Dong ${ }^{\star a b}$
}

Stimuli-responsive (such as voltage and/or light) fluorescence display systems have attracted particular attention in their promising fields of application. However, there are few examples of self-powered fluorescence display devices. Here we designed and fabricated a self-powered fluorescence display device based on a fast-charging/recharging battery. The specially designed battery was composed of a Prussian blue (PB) cathode and a magnesium metal anode with a high theoretical redox potential difference $(\sim 2.8 \mathrm{~V})$. Moreover, smartly adding a trace amount of $\mathrm{NaClO}$ in the electrolyte could realize oxidizing PW to PB $\sim 480$ times faster than when oxidizing without $\mathrm{NaClO}$, leading to the fast selfcharging and high power density (maximum power density of $13.34 \mathrm{~mW} \mathrm{~cm}^{-2}$, about two to three orders of magnitude larger than previous bio-fuel cells) of the Mg/PB battery. Most importantly, PB was used as not only the cathodic catalyst but also as an electrochromic material, making it possible to construct a self-powered and rechargeable electrochromic fluorescence display with only two electrodes. Besides, fluorescent $\left[\mathrm{Ru}(\mathrm{bpy})_{3}\right]^{2+}$-doped silica nanoparticles $\left(\mathrm{Ru}\left(\mathrm{aSiO}_{2}\right)\right.$, were selected as the fluorescence resonance energy transfer (FRET) donor to match PB (FRET acceptor). To the best of our knowledge, we demonstrated a self-powered and rechargeable electrochromic fluorescence display with only two electrodes for the first time.

Received 26th May 2016
Accepted 5th July 2016

DOI: $10.1039 / c 6 s c 02347 a$

www.rsc.org/chemicalscience

\section{Introduction}

Stimuli-responsive (such as voltage and/or light) fluorescence display systems have attracted particular attention in their promising fields of application. ${ }^{1}$ Generally, the fluorescence switching devices are based on optical coupling between the emission spectra of the selected fluorescent molecule and the absorption spectra of the electrochromic (or photochromic) material. Either a inner filter effect (IFE) ${ }^{2}$ or fluorescence resonance energy transfer (FRET) ${ }^{3}$ would occur between the fluorescent molecule (FRET donor) and the electrochromic (or photochromic) material (FRET acceptor), causing fluorescence quenching of the fluorescent molecule. Under stimulation, the electrochromic (or photochromic) material would display different absorbances, followed by variation of the fluorescence intensity. During the past decades, some fascinating research has been done. Jovin's group ${ }^{1 a}$ devised a family of photoswitchable QDs in which the donor-acceptor distance was varied systematically by attaching QD cores and photochromic

${ }^{a}$ State Key Laboratory of Electroanalytical Chemistry, Changchun Institute of Applied Chemistry, Chinese Academy of Science, Changchun, Jilin, 130022, P. R. China. E-mail:dongsj@ciac.ac.cn

${ }^{b}$ University of Chinese Academy of Sciences, Beijing, 100049, P. R. China

$\dagger$ Electronic supplementary information (ESI) available. See DOI: $10.1039 / \mathrm{c} 6 \mathrm{sc} 02347 \mathrm{a}$ diheteroarylethene groups via linkers of different lengths. Zhu's group $^{1 b}$ synthesized a new molecular structure of a trident perylenemonoimide modified by three photochromic dithienylethenes (1 donor-3 acceptors) with a high fluorescence switching speed. Besides, our group have also done some research into stimuli-responsive fluorescence displays, ${ }^{4}$ including photo-chem-electrotriggered three-state fluorescence switching. ${ }^{5}$ Nevertheless, most previous systems need external stimulation to operate, causing additional energy consumption. There were rare self-powered electrochromic devices, ${ }^{6}$ which had received much attention. However, those few self-powered electrochromic devices usually involved three electrodes (one electrochromic electrode, one anode and one cathode), which greatly enhanced the manufacturing process complexity.

To realize a self-powered electrochromic fluorescence device with less than three (only two) electrodes, it is necessary to integrate the electrochromic electrode with the anode (or cathode). In this regard, Prussian blue (PB), an excellent electrochromic material, is a good alternative, which can also be used as the cathodic catalyst, leading to the possibility of designing bifunctional devices. ${ }^{7}$ Moreover, self-charging batteries are of great interest due to the emerging problems of the energy crisis and environmental pollution. ${ }^{8} \mathrm{~A}$ self-charging and rechargeable PB battery makes it possible to realize a selfpowered fluorescence display with only two electrodes (PB could function as a cathode as well as an electrochromic electrode). 

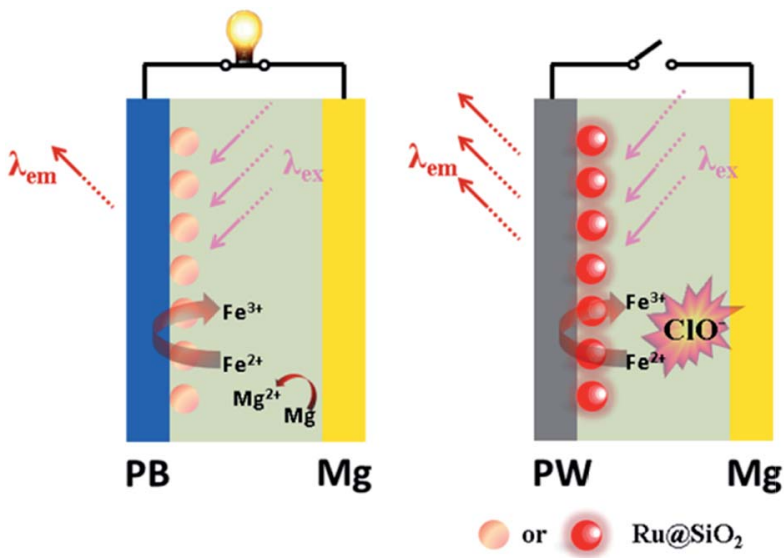

Fig. 1 The scheme of the self-powered electrochromic fluorescence device with only two electrodes.

However, the reported PB battery needs days to self-charge, ${ }^{9}$ and so could hardly be applied in fluorescence displays.

Here we demonstrate a self-powered electrochromic fluorescence display based on a fast self-charging and rechargeable $\mathrm{Mg} / \mathrm{PB}$ battery (Fig. 1). The device was composed of a PB cathode electrochemically deposited on a fluorine-doped tin oxide (FTO) glass, and a magnesium metal anode. Compared to metallic lithium, which is usually applied in Li-ion batteries, metallic magnesium is free from inherent poor stability and safety. ${ }^{10}$ Moreover, a strong oxidant solution, containing a trace amount of $\mathrm{NaClO}$, was used as electrolyte, which could oxidize the colorless PW to PB within a few minutes, realizing the fast selfcharging of the $\mathrm{Mg} / \mathrm{PB}$ battery. In addition, a fluorescent system of $\left[\mathrm{Ru}(\mathrm{bpy})_{3}\right]^{2+}$-doped silica nanoparticles $\left(\mathrm{Ru} @ \mathrm{SiO}_{2}\right)$, immobilized onto the surface of $\mathrm{PB}$, was selected as the FRET donor, since its emission bands overlap well with the absorption spectrum of $\mathrm{PB}$ and it could maintain its fluorescence in the strong oxidizing electrolyte. Lastly, Nafion was dropped on the surface of $\mathrm{Ru} @ \mathrm{SiO}_{2}$ to avoid the leaking of $\mathrm{Ru} @ \mathrm{SiO}_{2}$. Thus, an electrochromic fluorescence display, $\mathrm{PB} / \mathrm{Ru} @ \mathrm{SiO}_{2} / \mathrm{Nafion}$, was constructed successfully, and the fluorescence could be switched "on" and "off" by simply "connecting" and "disconnecting" PB and Mg. For the first time, a self-powered electrochromic fluorescence display with only two electrodes was proposed.

\section{Experimental}

\section{Materials and methods}

Triton X-100 and NaClO were purchased from Sigma. Tris(2,2'bipyridyl)dichlororuthenium(II)hexahydrate $\left(\mathrm{Ru}(\mathrm{bpy})_{3} \mathrm{Cl}_{2} \cdot 6 \mathrm{H}_{2}-\right.$ O) was obtained from Aldrich. Tetraethylorthosilicate (TEOS) was bought from Beijing Yili Chemical Reagent. $\mathrm{K}_{2} \mathrm{HPO}_{4} \cdot 3 \mathrm{H}_{2} \mathrm{O}$ and $\mathrm{KH}_{2} \mathrm{PO}_{4}$ were used to prepare the phosphate buffer. All of the other chemicals were of analytical grade and were used without further purification. Ultrapure water $(>18 \mathrm{M} \Omega)$ from Water Purifier (Sichuan Water Purifier Co., Ltd., China) was utilized throughout the experiments. The single-side conductive
FTO chips (transmittance $>83 \%$, sheet resistance $<15 \Omega \mathrm{sq}^{-1}$ ) were purchased from Zhuhai Kaivo Optoelectronic Technology Co., Ltd., China.

The absorption measurements were carried out on a Cary 500 UV-vis-NIR spectrometer (Varian). Photoluminescence measurements were conducted with a Fluoromax-4 spectrofluorometer (Horiba Jobin Yvon Inc., France); the excitation and emission slit widths were $5 \mathrm{~nm}$. Electrochemical experiments were performed on a $\mathrm{CHI} 660$ electrochemical workstation.

\section{Synthesis of PB film}

Before modification, the FTO glasses (trapezoid, $(0.570+$ $0.840) / 2 \times 5.300 \mathrm{~cm}^{2}$ ) were cleaned with acetone, ethanol and water in an ultrasonic bath each for $10 \mathrm{~min}$. Then the FTO chips were immersed in an activation solution containing $1: 1$ $(\mathrm{v} / \mathrm{v})$ ethanol/NaOH $(1 \mathrm{M})$ for $15 \mathrm{~min}$. After being thoroughly rinsed with water and dried with nitrogen, the FTO sheets were electropolymerized with PB by applying a constant potential of $0.4 \mathrm{~V}$ for $500 \mathrm{~s}$. An aqueous solution which consisted of $0.1 \mathrm{M}$ $\mathrm{KCl}, 0.1 \mathrm{M} \mathrm{HCl}, 2.5 \mathrm{mM} \mathrm{K}_{3}\left[\mathrm{Fe}(\mathrm{CN})_{6}\right]$ and $2.5 \mathrm{mM} \mathrm{FeCl}_{3}$ was employed as the electrolyte for PB electrochemical deposition. ${ }^{11}$ Meanwhile the FTO chip, Pt sheet and $\mathrm{Ag} / \mathrm{AgCl}$ (saturated $\mathrm{KCl}$ ) were utilized as the working electrode, counter electrode and reference electrode, respectively. Finally, the asprepared PB electrodes were dried at $100{ }^{\circ} \mathrm{C}$ for $5-6 \mathrm{~h}$ after being thoroughly rinsed with water, and stored in a centrifuge tube shielded from light.

\section{Preparation of the $\mathbf{M g} / \mathrm{PB}$ battery and electrochemical measurements}

The battery was composed of a PB cathode and a metallic $\mathrm{Mg}$ anode. The slim $\mathrm{Mg}$ rod was wrapped with insulation tape with a section $\left(0.192 \times 0.312 \mathrm{~cm}^{2}\right)$ uncovered. A strong oxidant solution composed of $0.025 \mathrm{M} \mathrm{NaClO}, 1 \mathrm{M} \mathrm{KCl}$, and $0.1 \mathrm{M}$ phosphate buffer ( $\mathrm{pH}$ 6) was used as the electrolyte. The charging and discharging process of the $\mathrm{Mg} / \mathrm{PB}$ battery was achieved by disconnecting and connecting $\mathrm{PB}$ and $\mathrm{Mg}$ electrodes. When detecting the open circuit potential and power of the $\mathrm{Mg} / \mathrm{PB}$ battery, $\mathrm{Mg}$ served as both the counter and reference electrode. The uncovered section of $\mathrm{Mg}$ rod was polished before each test.

\section{Synthesis of $\mathrm{Ru} @ \mathrm{SiO}_{2}$ nanoparticles}

The $\mathrm{Ru} @ \mathrm{SiO}_{2}$ nanoparticles were prepared as previously described. ${ }^{12}$ Briefly, cyclohexane $(7.5 \mathrm{~mL})$, Triton X-100 $(1.77 \mathrm{~mL}), 1$-hexanol $(1.8 \mathrm{~mL})$ and water $(340 \mu \mathrm{L})$ were mixed together at the beginning. Then $\left[\mathrm{Ru}(\mathrm{bpy})_{3}\right]^{2+}(0.1 \mathrm{M}, 80 \mu \mathrm{L})$ was added under magnetic stirring. After introduction of TEOS (100 $\mu \mathrm{L}$ ), the mixture solution was kept stirring for $30 \mathrm{~min}$. Finally, a polymerization reaction was initiated by injecting ammonia $(25 \%, 60 \mu \mathrm{L})$. After the reaction was completed within $24 \mathrm{~h}$, the $\mathrm{Ru} @ \mathrm{SiO}_{2}$ nanoparticles were isolated using acetone, and washed with ethanol and water several times. The orange precipitates were dried under $80{ }^{\circ} \mathrm{C}$ temperature to obtain completely dry products. 


\section{Preparation of $\mathrm{PB} / \mathrm{Ru} @ \mathrm{SiO}_{2} / \mathrm{Nafion}$ film and optical measurements}

A Ru@SiO ${ }_{2}\left(10 \mu \mathrm{L}, 1 \mathrm{mg} \mathrm{mL}^{-1}\right)$ aqueous solution was dropped on the surface of PB. After being dried at ambient temperature, Nafion $(10 \mu \mathrm{L}, 0.2 \%)$ was dropped on the surface of $\mathrm{Ru} @ \mathrm{SiO}_{2}$ to avoid the leaking of $\mathrm{Ru} @ \mathrm{SiO}_{2}$. In the $\mathrm{Mg} / \mathrm{PB}$ battery system, the $\mathrm{PB} / \mathrm{Ru} @ \mathrm{SiO}_{2} / \mathrm{Nafion}$ film functioned as the fluorescence display. The switch on and off of the fluorescence display was realized by connecting and disconnecting the $\mathrm{PB}$ cathode and the $\mathrm{Mg}$ anode.

The online photoluminescence measurements were performed on a home built cuvette. ${ }^{13}$ The cuvette was capped with a Teflon plate to support the electrodes, with the PB film glasses kept at a 45 angle to the excitation light source and the detector (the detector is vertical to the excitation light source in a spectrofluorometer). At the same time the absorption measurements were conducted with another Teflon plate, and the PB film electrode was kept vertical to the excitation light path (the detector is in the excitation light path in a UV-vis-NIR spectrometer).

\section{Results and discussion}

\section{The $\mathrm{Mg} / \mathrm{PB}$ battery}

The redox potential of the electrode reaction was demonstrated firstly.

$$
\begin{gathered}
\mathrm{Mg} \rightarrow \mathrm{Mg}^{2+}+2 \mathrm{e}^{-},-2.37 \mathrm{~V}(v s . \mathrm{SHE}) \\
\mathrm{PB} \rightarrow \mathrm{PW},+0.43 \mathrm{~V}(\text { vs. SHE })
\end{gathered}
$$

The oxidation potential of $\mathrm{PB}$ was much higher than $\mathrm{Mg}$, indicating the feasibility of $\mathrm{Mg} / \mathrm{PB}$ battery. The great redox potential difference $(\sim 2.8 \mathrm{~V})$ might promise wonderful battery behavior of the $\mathrm{Mg} / \mathrm{PB}$ system.

The proposed battery system was composed of a PB cathode electrochemically deposited on a single-side conductive FTO glass and a $\mathrm{Mg}$ metal anode $\left(0.192 \times 0.312 \mathrm{~cm}^{2}\right)$. Briefly, the PB film was polymerized in a mixture of $\mathrm{K}_{3}\left[\mathrm{Fe}(\mathrm{CN})_{6}\right]$ and $\mathrm{FeCl}_{3}$ as the electrolyte. The original transparent FTO exhibited a blue color after the electrodeposition procedure, confirming the successfully preparation of the PB film. The morphology and structure of these PB chips were characterized using scanning electron microscopy (SEM). A uniform surface was observed (Fig. S1†). Moreover, while investigating its electrochromic properties, PB displayed outstanding reversibility, and excellent long-time stability (Fig. S2 $\dagger$ ), which laid a favorable foundation for repeatable chemical recovery from $\mathrm{PW}$ to $\mathrm{PB}$ (vide infra).

Next, the $\mathrm{Mg} / \mathrm{PB}$ battery was assembled by connecting the PB cathode and $\mathrm{Mg}$ anode with $1 \mathrm{M} \mathrm{KCl}$ and $0.1 \mathrm{M}$ phosphate buffer (pH 6) as the electrolyte. PB changed from blue to colourless to form PW on connecting $\mathrm{PB}$ and $\mathrm{Mg}$, which was the discharging process of the $\mathrm{Mg} / \mathrm{PB}$ battery (Fig. 2C, red curve). The absorbance of PB was decreased by $91.7 \%$ in the initial $4.2 \mathrm{~s}$ and $97.8 \%$ in total over 10.0 s. On disconnecting PB and $\mathrm{Mg}, \mathrm{PW}$ was oxidized to form $\mathrm{PB}$ by dissolved oxygen in the solution and
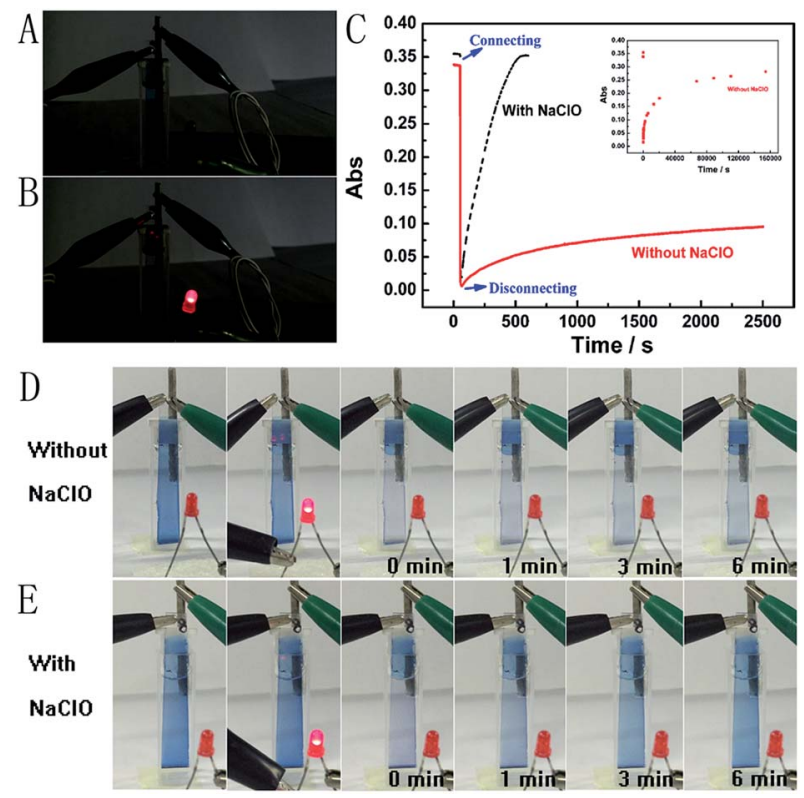

Fig. 2 Photographs of the Mg/PB battery with two electrodes disconnected (A) and connected (B). (C) In situ absorbance measurement of the $\mathrm{Mg} / \mathrm{PB}$ battery connected at $50 \mathrm{~s}$ and then disconnected at $60 \mathrm{~s}$. The red curve refers to the electrolyte containing $1 \mathrm{M} \mathrm{KCl}$ and $0.1 \mathrm{M}$ phosphate buffer $(\mathrm{pH} \mathrm{6})$, and the black curve refers to the electrolyte containing $0.025 \mathrm{M} \mathrm{NaClO}, 1 \mathrm{M} \mathrm{KCl}$ and $0.1 \mathrm{M}$ phosphate buffer $(\mathrm{pH} 6)$. Inset: the complete recovery process of PW in the electrolyte without $\mathrm{NaClO}$. The corresponding photographs of the red and black curves are (D) and (E), respectively. The first and second pictures refer to the Mg/PB battery with two electrodes disconnected and connected. The next four pictures refer to the two electrodes disconnecting for $0,1,3$ and 6 min.

the transparent PW turned to blue, which showed the charging process of the battery. However, this charging process was too slow. For $26.1 \%$ and $82.7 \%$ absorbance increases (within the total $97.8 \%$ absorbance decrease obtained in the initial $10 \mathrm{~s}$ ), the corresponding recovery times were $40.0 \mathrm{~min}$ and $42.8 \mathrm{~h}$, respectively.

The spontaneous oxidation of PW to PB depending on the dissolved oxygen was too slow, therefore the $\mathrm{Mg} / \mathrm{PB}$ battery could not be used as a self-charging power source. To solve this problem, we argued to increase the oxidability of the electrolyte solution. And a trace amount of NaClO could be greatly helpful. By means of an optimization test, the final electrolyte solution was composed of $0.025 \mathrm{M} \mathrm{NaClO}, 1 \mathrm{M} \mathrm{KCl}$, and $0.1 \mathrm{M}$ phosphate buffer ( $\mathrm{pH}$ 6). In these conditions (Fig. 2C, black curve), the absorbance of PB was decreased by $95.1 \%$ in the initial $10.0 \mathrm{~s}$ (connecting $\mathrm{PB}$ and $\mathrm{Mg}$, discharging process, $\mathrm{PB}$ to $\mathrm{PW}$, bleaching) and increased by $90 \%$ in the next 6.24 min (disconnecting $\mathrm{PB}$ and $\mathrm{Mg}$, charging process, $\mathrm{PW}$ to $\mathrm{PB}$, colouration). The corresponding movies are available in ESI Movies 1 and $2, \uparrow$ which visually show the different recovery times of PW in the electrolyte with and without NaClO. Compared with the $\mathrm{Mg} / \mathrm{PB}$ battery without NaClO electrolyte (colouration for $82.7 \%$, $42.8 \mathrm{~h}$ ), the proposed PB system exhibited a notably high colouration speed. It only needed 5.35 min to undergo colouration of $82.7 \%, \sim 480$ times faster than the battery without NaClO. 
And a rapid colouration speed means a quick charging process. Considering our proposed battery is self-charging, the ability for fast self-charging is prominent and favourable for practical applications. This fascinating character was attributed to the strong oxidant $\mathrm{NaClO}$ in the electrolyte solution. NaClO could oxidize PW to PB quickly. Meanwhile, the absorbance of PB could almost $100 \%$ recover to its original value, that is to say, the $\mathrm{Mg} / \mathrm{PB}$ battery could fully self-charge within $\sim 6$ minutes. Simultaneously, the bleaching speed (bleaching over 95\%, $10 \mathrm{~s}$ ) in a solution with and without $\mathrm{NaClO}$ is comparable, and negligible interference from $\mathrm{NaClO}$ was confirmed. By the way, some other oxidants, such as $\mathrm{H}_{2} \mathrm{O}_{2}$ and $\left(\mathrm{NH}_{4}\right)_{2} \mathrm{~S}_{2} \mathrm{O}_{8}$, were also effective to replace $\mathrm{NaClO}$ in the system (Fig. S3†). Although more optimization of experimental conditions (the $\mathrm{pH}$, the temperature or the concentration of the oxidant) should be done to get a satisfactory self-charging speed, the universality of the design by introducing an oxidant into battery electrolyte is a very promising prospect.

The open circuit potential measurements were taken in a twoelectrode configuration with the slim $\mathrm{Mg}$ rod serving as both the counter and reference electrode. The measured open circuit potential of the $\mathrm{Mg} / \mathrm{PB}$ battery was $2.50 \mathrm{~V}$, which is higher than for previously reported electrochromic batteries $\left(1.26 \mathrm{~V}^{9}\right.$ $0.87 \mathrm{~V}) .{ }^{14}$ And just one battery could light up a red LED (Fig. 2B). To elucidate more about the high open circuit potential, some detailed experiments were carried out. The cathode (PB) and anode $(\mathrm{Mg})$ potentials of the battery were $0.68 \mathrm{~V}$ and $1.82 \mathrm{~V}$, respectively. Strangely, according to the previous reports, ${ }^{7 a, 9}$ the cathode (PB) potential should be approximately $0.35 \mathrm{~V}$ (vs. $\mathrm{Ag} / \mathrm{AgCl}$ ). We suggested that the strong oxidant electrolyte solution might account for this difference. To verify this hypothesis, the cathode and anode potential were detected once again in a electrolyte without $\mathrm{NaClO}$ (only containing $1 \mathrm{M} \mathrm{KCl}$ and 0.1 $\mathrm{M}$ phosphate buffer ( $\mathrm{pH}$ 6)). Then the cathode and anode potentials were $0.37 \mathrm{~V}$ and $1.78 \mathrm{~V}$, respectively. Inspired by the observed experimental facts, it became evident that $\mathrm{NaClO}$ played a momentous role in increasing the cathode potential.

Another significant experimental parameter for batteries is power. Taking the small active area of the trapezoidal PB film $\left((0.610+0.840) / 2 \times 3.130 \mathrm{~cm}^{2}\right)$ into account, the power of this $\mathrm{Mg} / \mathrm{PB}$ battery was detected using a method normally used in biofuel cells. ${ }^{15}$ In a quiescent solution, the maximum current density of the battery was $7.85 \mathrm{~mA} \mathrm{~cm} \mathrm{~cm}^{-2}$ and the maximum power density was $13.34 \mathrm{~mW} \mathrm{~cm}^{-2}$ (about two to three orders of magnitude larger than previous bio-fuel cells $)^{16}$ at $1.70 \mathrm{~V}$ of the cell voltage, according to the geometrical surface of the $\mathrm{Mg}$ electrode (Fig. 3). For comparison, the power density was also monitored in an electrolyte without $\mathrm{NaClO}$, since $\mathrm{NaClO}$ may be helpful to improve the power output. In that case, the maximum power density was decreased to nearly $3 \mathrm{~mW} \mathrm{~cm}^{-2}$. Thus, $\mathrm{NaClO}$ not only accelerated the oxidation of $\mathrm{PW}$, making the $\mathrm{Mg} / \mathrm{PB}$ battery a fast self-charging one, but also was involved in augmenting the open circuit potential and power density of this battery. Table $\mathrm{S} 1 \dagger$ summarizes the differences in the battery behavior between the electrolyte with and without NaClO.

We further characterized the $\mathrm{Mg} / \mathrm{PB}$ battery in terms of rechargeable acceptance ability. Fortunately, the apparent

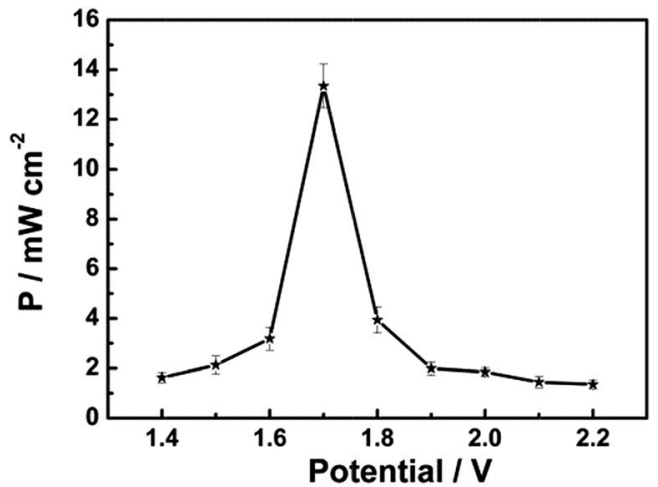

Fig. 3 Dependence of the power density on the cell voltage for the assembled $\mathrm{Mg} / \mathrm{PB}$ battery in $0.025 \mathrm{M} \mathrm{NaClO}, 1 \mathrm{M} \mathrm{KCl}$ and $0.1 \mathrm{M}$ phosphate buffer $(\mathrm{pH}$ 6) electrolyte, quiescent solution, under air.

structure of PB did not present great changes after one discharging and charging cycle in an appropriate concentration of $\mathrm{NaClO}$, which was confirmed via the SEM images of PB before and after one cycle. After three cycles, the recovered $\mathrm{Mg} / \mathrm{PB}$ battery could still deliver a maximum power density of $12.96 \mathrm{~mW} \mathrm{~cm}^{-2}$, with a total loss of $3 \%$ compared with the first discharge process (Fig. 4A). In addition, the maximum power density decreased $21 \%$ after cycling five times. However, from the absorbance spectra, during seven cycles the $\mathrm{Mg} / \mathrm{PB}$ battery could maintain over $80 \%$ of the original absorbance value before the test (Fig. 4B). Although the PW recovery process was slowing because of the consumption of $\mathrm{NaClO}$, the maximum recovery time was still within $1000 \mathrm{~s}$ in the last (seventh) cycle.

The functioning mechanisms of the fast self-charging and rechargeable $\mathrm{Mg} / \mathrm{PB}$ battery could be illustrated as follows (Fig. $\mathrm{S} 4 \dagger$ ): $\mathrm{Mg}$ is a highly active metal, showing strong reducibility. When connecting $\mathrm{PB}$ and $\mathrm{Mg}, \mathrm{Mg}$ released electrons to form $\mathrm{Mg}^{2+}$ ions, and $\mathrm{PB}$ accepted electrons to form PW.

Half-cell reactions:

Anode

$$
\mathrm{Mg}=\mathrm{Mg}^{2+}+2 \mathrm{e}^{-}
$$

Cathode

$$
\mathrm{KFe}^{\mathrm{III}}\left[\mathrm{Fe}^{\mathrm{II}}(\mathrm{CN})_{6}\right](\mathrm{PB})+\mathrm{K}^{+}+\mathrm{e}^{-}=\mathrm{K}_{2} \mathrm{Fe}^{\mathrm{II}}\left[\mathrm{Fe}^{\mathrm{II}}(\mathrm{CN})_{6}\right](\mathrm{PW})
$$
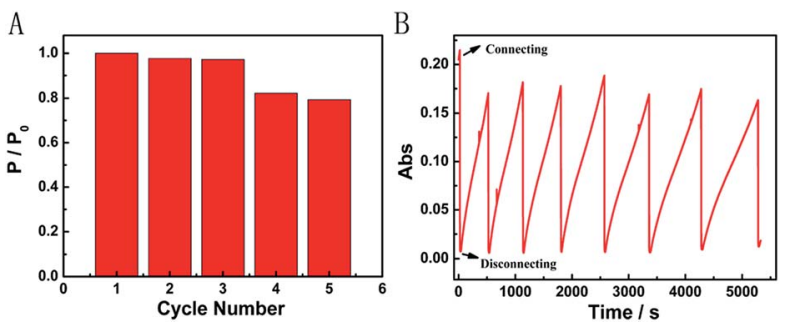

Fig. 4 (A) Repeated rechargeability test of the self-powered Mg/PB battery by simply disconnecting $\mathrm{PB}$ and $\mathrm{Mg}$ in $0.025 \mathrm{M} \mathrm{NaClO}, 1 \mathrm{M} \mathrm{KCl}$ and $0.1 \mathrm{M}$ phosphate buffer ( $\mathrm{pH}$ 6) electrolyte. (B) In situ absorbance measurement of the $\mathrm{Mg} / \mathrm{PB}$ battery under repeated discharging and charging cycles. 
The overall cell reaction can be expressed as:

$$
\begin{aligned}
& 2 \mathrm{KFe}^{\mathrm{III}}\left[\mathrm{Fe}^{\mathrm{II}}(\mathrm{CN})_{6}\right](\mathrm{PB})+2 \mathrm{~K}^{+}+\mathrm{Mg}= \\
& 2 \mathrm{~K}_{2} \mathrm{Fe}^{\mathrm{II}}\left[\mathrm{Fe}^{\mathrm{II}}(\mathrm{CN})_{6}\right](\mathrm{PW})+\mathrm{Mg}^{2+}
\end{aligned}
$$

The bleached device recovered its blue colour after being oxidized by $\mathrm{NaClO}$; this charging process could be described by the following reaction:

$$
\begin{aligned}
& 2 \mathrm{~K}_{2} \mathrm{Fe}^{\mathrm{II}}\left[\mathrm{Fe}^{\mathrm{II}}(\mathrm{CN})_{6}\right](\mathrm{PW})+\mathrm{NaClO}+2 \mathrm{H}^{+}= \\
& 2 \mathrm{KFe}^{\mathrm{III}}\left[\mathrm{Fe}^{\mathrm{II}}(\mathrm{CN})_{6}\right](\mathrm{PB})+2 \mathrm{~K}^{+}+\mathrm{NaCl}+\mathrm{H}_{2} \mathrm{O}
\end{aligned}
$$

It is worth noting that, the reaction (4) still exists even in the discharging process. Despite the coexistence of reactions (3) (PB to $\mathrm{PW}$ ) and (4) (PW to $\mathrm{PB}$ ), the reaction rate of (3) is much higher than that of (4). While connecting $\mathrm{PB}$ and $\mathrm{Mg}$, reaction (3) is dominant and the colour variation of the FTO glass just could be observed from blue to transparent. The coexistence of reaction (3) with reaction (4) probably explained why $\mathrm{NaClO}$ is favourable for increasing the open circuit potential of the battery. Besides, dissolved oxygen in the solution is also active in the process.

Why would the trace amount of NaClO have an important effect on the oxidation of PW? To gain more insight, the redox potential during the recharging process was demonstrated.

$$
\begin{gathered}
\mathrm{PW} \rightarrow \mathrm{PB},-0.43 \mathrm{~V}(v s . \mathrm{SHE}) \\
\mathrm{HClO}+\mathrm{H}^{+}+2 \mathrm{e}^{-} \rightarrow \mathrm{Cl}^{-}+\mathrm{H}_{2} \mathrm{O},+1.482 \mathrm{~V}(v s . \mathrm{SHE})
\end{gathered}
$$

The standard reduction potential of $\mathrm{HClO}$ was high in acidic solution. This probably explained why the trace amount of NaClO would greatly accelerate the oxidation of PW. By contrast, the spontaneous oxidation of $\mathrm{PW}$ to $\mathrm{PB}$ relying on dissolved oxygen was too slow, owing to the relatively weak oxidizability of oxygen.

\section{The fluorescence displays}

The broad market for electronics devices suffers from manufacturing process complexities. One solution is to develop integrated multifunctional devices. Since the PB device is not only a fast self-charging and rechargeable battery but also a smart electrochromic window, we could design a self-powered electrochromic fluorescence display with only two electrodes for the first time.

The $\mathrm{Ru} @ \mathrm{SiO}_{2}$ functioned as the fluorescent molecule to match electrochromic $\mathrm{PB}$. On the one hand, the emission peak of $\mathrm{Ru} @ \mathrm{SiO}_{2}$ was located at $649 \mathrm{~nm}$ and overlapped well with the absorption spectra of PB (Fig. 6A). So, effective IFE or FRET would occur when Ru@SiO ${ }_{2}$ was immobilized on the surface of $\mathrm{PB}$. On the other hand, $\mathrm{Ru@SiO}{ }_{2}$ could maintain its fluorescence in the strong oxidizing electrolyte solution, while some other fluorescent probes, such as nanoclusters or quantum dots were quenched. Lastly, Nafion was dropped on the surface of $\mathrm{Ru} @ \mathrm{SiO}_{2}$ to avoid the leaking of $\mathrm{Ru} @ \mathrm{SiO}_{2}$, thus an electrochromic fluorescence display, $\mathrm{PB} / \mathrm{Ru} @ \mathrm{SiO}_{2} / \mathrm{Nafion}$,
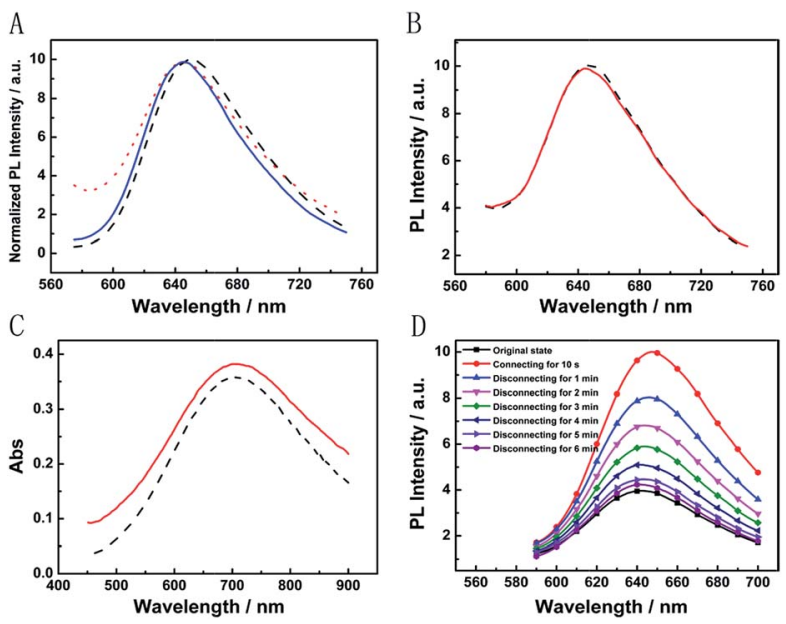

Fig. 5 (A) Emission spectra of $0.1 \mathrm{mg} \mathrm{mL}^{-1} \mathrm{RuQSiO}_{2}$ aqueous solution (black dash curve), the RuaSiO $2 / N a f i o n$ film electrode (red dot curve) and the $\mathrm{PB} / \mathrm{RuaSiO} /$ Nafion film electrode (blue solid curve). (B) Emission spectra of the RuaSiO 2 /Nafion film electrode before (black dash curve) and after (red solid curve) connecting with $\mathrm{Mg}$. (C) Absorption spectra of the PB (black dash curve) and PB/Ru@SiO ${ }_{2} /$ Nafion (red solid curve) film electrode. (D) Emission spectra of the PB/ RuaSiO $/$ Nafion film electrode while connecting and disconnecting with $\mathrm{Mg}$.

was constructed successfully. Detailed experimental manipulation is revealed in the experimental section and the characterization is described in Fig. S5 to S8. $\dagger$ The average $\mathrm{Ru@SiO} \mathrm{S}_{2}$ crystalline sizes could be roughly calculated to be $79.0 \pm 7.2 \mathrm{~nm}$ from the TEM image (Fig. S5 $\dagger$ ). Moreover, several control experiments have been performed. (1) $\mathrm{Ru} @ \mathrm{SiO}_{2}$ was stable both in an aqueous solution and on the surface of PB (Fig. 5A). (2) The fluorescence of $\mathrm{Ru@SiO} /$ Nafion film (without $\mathrm{PB}$ ) would not change while connecting with $\mathrm{Mg}$ (Fig. 5B). (3) The Ru@SiO ${ }_{2}$ on the surface of PB could not influence the absorbance of PB (Fig. 5C). (4) The emission peak of the $\mathrm{PB} / \mathrm{Ru} @ \mathrm{SiO}_{2} / \mathrm{Nafion}$ film electrode decreased when the time of disconnecting with $\mathrm{Mg}$ was prolonged, and $\sim 6$ min was required to restore the original value of fluorescence (Fig. 5D).

Fig. 6B presents the emission spectra variation of the $\mathrm{PB} /$ $\mathrm{Ru} @ \mathrm{SiO}_{2} /$ Nafion film during charging and discharging cycles.
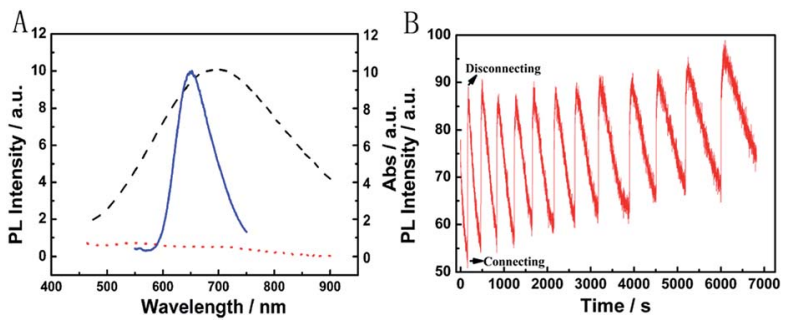

Fig. 6 (A) Absorption spectra of the PB film before (black curve) and after (red curve) the connecting of PB and $\mathrm{Mg}$. The emission spectra of $\mathrm{RuaSiO}_{2}$ (blue curve); the sample was excited at $465 \mathrm{~nm}$. (B) Fluorescence at $649 \mathrm{~nm}$ of the $\mathrm{PB} / \mathrm{Ru}\left(\mathrm{SSiO}_{2} / \mathrm{Nafion}\right.$ film as a function of time upon repeated discharging and charging cycles. 
Initially, the fluorescence of $\mathrm{Ru} @ \mathrm{SiO}_{2}$ was weak because of the strong absorbance of $\mathrm{PB}$. When connecting $\mathrm{PB}$ and $\mathrm{Mg}$ (the discharging process), the absorbance of $\mathrm{PB}$ was drastically reduced and transparent PW was formed. Thus $\mathrm{Ru@SiO}$ returned to its intrinsic fluorescence intensity. When disconnecting $\mathrm{PB}$ and $\mathrm{Mg}$ afterwards (the charging process), $\mathrm{PW}$ was oxidized to $\mathrm{PB}$, and the absorbance increased slowly, leading to the fluorescence decrease of $\mathrm{Ru@SiO}{ }_{2}$ simultaneously. Detailed information about Fig. 6B is shown in Table $\mathrm{S} 2 . \dagger$ The biggest fluorescence contrast and shortest recovery time were $63 \%$ and $290 \mathrm{~s}$ at the first cycle. The fluorescence contrast remained over $50 \%$ for six cycles with recovery times less than $500 \mathrm{~s}$. Even after ten cycles, the PB/Ru@ $\mathrm{SiO}_{2} / \mathrm{Nafion}$ film presented nearly $40 \%$ fluorescence contrast and a $660 \mathrm{~s}$ recovery time, indicating that the self-powered electrochromic fluorescence display is highly reversible and timesaving. The excellent performance of the self-powered electrochromic fluorescence display device can be attributed to the wonderful property of the $\mathrm{Mg} / \mathrm{PB}$ battery as well as the efficient IFE and FRET between PB and Ru@SiO ${ }_{2}$. So far, the proposed device could be considered as a fast self-charging/ recharging electrochromic fluorescence display with only two electrodes.

\section{Conclusions}

In summary, we have successfully realized a self-powered electrochromic fluorescence display based on a fast selfcharging and rechargeable $\mathrm{Mg} / \mathrm{PB}$ battery by introducing a trace amount of strong oxidant $\mathrm{NaClO}$ into the electrolyte. By simply connecting $\mathrm{Mg}$ and $\mathrm{PB}$ electrodes, just one battery could light up an LED. Afterwards, on disconnecting the $\mathrm{Mg}$ and PB electrodes, the battery could be self-charged within $\sim 6$ min, $\sim 480$ times faster than the battery without NaClO. During this process, PB contributed high power density and excellent cycling performance when evaluated as a cathode. The trace amount of NaClO played a central role in improving the battery behavior. Based on the encouraging performance of this battery, a self-powered electrochromic fluorescence device with only two electrodes was proposed for the first time. Further work might focus on the introduction of a gel or solid electrolyte to improve the device performance. Considering PW is transparent, and the $\mathrm{Mg} / \mathrm{PB}$ battery could be a "half" transparent battery, our proposed device provides possibilities to develop transparent batteries used also as an electronic display screen. We anticipate that the proposed fast selfcharging and rechargeable electrochromic fluorescence display would offer a solution to the emerging power supply problem of the next-generation, transparent portable electronic devices.

\section{Acknowledgements}

This work is supported by the National Natural Science Foundation of China (No. 21375123) and the Ministry of Science and Technology of China (No. 2013YQ170585).

\section{Notes and references}

1 (a) S. A. Diaz, F. Gillanders, E. A. Jares-Erijman and T. M. Jovin, Nat. Commun., 2015, 6, 6036-6046; (b) C. Li, H. Yan, L. X. Zhao, G. F. Zhang, Z. Hu, Z. L. Huang and M. Q. Zhu, Nat. Commun., 2014, 5, 5709-5719; (c) A. Beneduci, S. Cospito, M. L. Deda and G. Chidichimo, Adv. Funct. Mater., 2015, 25, 1240-1247; (d) G. F. Cai, M. Q. Cui, V. Kumar, P. Darmawan, J. X. Wang, X. Wang, A. L. Eh, K. Qian and P. S. Lee, Chem. Sci., 2016, 7, 13731382; (e) Y. M. Zhang, W. Li, X. J. Wang, B. Yang, M. J. Li and S. X. A. Zhang, Chem. Commun., 2014, 50, 1420-1422; (f) H. X. Gu, L. H. Bi, Y. Fu, N. Wang, S. Q. Liu and Z. Y. Tang, Chem. Sci., 2013, 4, 4371-4376; ( $g$ ) I. L. Medintz, S. A. Trammell, H. Mattoussi and J. M. Mauro, J. Am. Chem. Soc., 2004, 126, 30-31; (h) K. Nakamura, K. Kanazawa and N. Kobayashi, Chem. Commun., 2011, 47, 10064-10066; (i) L. Zhu, M. Q. Zhu, J. K. Hurst and A. D. Li, J. Am. Chem. Soc., 2005, 127, 8968-8970; (j) Y. Kim, E. Kim, G. Clavier and P. Audebert, Chem. Commun., 2006, 3612-3614; ( $k$ ) J. de Torres, P. Ferrand, G. Colas des Francs and J. Wenger, ACS Nano, 2016, 10, 3968-3976; (l) P. Zrazhevskiy, L. D. True and X. Gao, Nat. Protoc., 2013, 8, 1852-1869; $(m)$ R. Yoshii, A. Hirose, K. Tanaka and Y. Chujo, J. Am. Chem. Soc., 2014, 136, 18131-18139.

2 L. Shang and S. J. Dong, Anal. Chem., 2009, 81, 1465-1470. 3 (a) J. J. Davis, H. Burgess, G. Zauner, S. Kuznetsova, J. Salverda, T. Aartsma and G. W. Canters, J. Phys. Chem. B, 2006, 110, 20649-20654; (b) S. Buckhout-White, C. M. Spillmann, W. R. Algar, A. Khachatrian, J. S. Melinger, E. R. Goldman, M. G. Ancona and I. L. Medintz, Nat. Commun., 2014, 5, 5615-5630; (c) Y. Y. Yuan, R. Y. Zhang, X. M. Cheng, S. D. Xu and B. Liu, Chem. Sci., 2016, 4245-4250.

4 L. H. Jin, Y. X. Fang, D. Wen, L. Wang, E. K. Wang and S. J. Dong, ACS Nano, 2011, 5, 5249-5253.

5 Y. L. Zhai, Z. J. Zhu, C. Z. Zhu, J. Zhu, J. T. Ren, E. K. Wang and S. J. Dong, Nanoscale, 2013, 5, 4344-4350.

6 (a) L. Bai, L. H. Jin, L. Han and S. J. Dong, Energy Environ. Sci., 2013, 6, 3015-3021; (b) M. Möller, N. Leyland, G. Copeland and M. Cassidy, Eur. Phys. J.: Appl. Phys., 2010, 51, 3320533207.

7 (a) A. Eftekhari, J. Power Sources, 2004, 126, 221-228; (b) L. Zhang, H. B. Wu, S. Madhavi, H. H. Hng and X. W. Lou, J. Am. Chem. Soc., 2012, 134, 17388-17391; (c) C. D. Wessells, R. A. Huggins and Y. Cui, Nat. Commun., 2011, 2, 550; (d) V. D. Neff, J. Electrochem. Soc., 1985, 132, 1382-1384; (e) K. Itaya, I. Uchida and V. D. Neff, Acc. Chem. Res., 1986, 19, 162-168; (f) S. Ferlay, T. Mallah, R. Ouahès, P. Veillet and M. Verdaguer, Nature, 1995, 378, 701-703; $(g)$ K. Itaya, N. Shoji and I. Uchida, J. Am. Chem. Soc., 1984, 106, 3423-3429; (h) F. R. Wells, Nature, 1962, 195, 188-189; (i) C. O'Dwyer, M. Szachowicz, G. Visimberga, V. Lavayen, S. B. Newcomb and C. M. Sotomayor Torres, Nat. Nanotechnol., 2009, 4, 239-244; (j) M. Hu, S. Furukawa, R. Ohtani, H. Sukegawa, Y. Nemoto, J. Reboul, S. Kitagawa 
and Y. Yamauchi, Angew. Chem., Int. Ed., 2012, 51, 984-988; (k) M. Zhou, H. L. Wang and S. Guo, Chem. Soc. Rev., 2016, 45, 1273-1307; (l) A. Prabhu, J. Bobacka, A. Ivaska and K. Levon, Electroanalysis, 2013, 25, 1887-1894; $(m) \mathrm{M} . \mathrm{Hu}$, A. A. Belik, M. Imura and Y. Yamauchi, J. Am. Chem. Soc., 2013, 135, 384-391; (n) M. Hu, A. A. Belik, M. Imura, K. Mibu, Y. Tsujimoto and Y. Yamauchi, Chem. Mater., 2012, 24, 2698-2707; (o) N. L. Torad, M. Hu, M. Imura, M. Naito and Y. Yamauchi, J. Mater. Chem., 2012, 22, 18261-18267.

8 (a) M. C. Lin, M. Gong, B. Lu, Y. Wu, D. Y. Wang, M. Guan, M. Angell, C. Chen, J. Yang, B. J. Hwang and H. Dai, Nature, 2015, 520, 325-328; (b) B. Zhang and C. Cao, Nature, 2015, 517, 433-434; (c) Y. S. Liu, Y. H. Li and C. Chen, Nature, 2015, 517, 145; (d) Z. H. Gong, Nature, 2015, 517, 145.

9 J. M. Wang, L. Zhang, L. Yu, Z. H. Jiao, H. Q. Xie, X. W. Lou and X. W. Sun, Nat. Commun., 2014, 5, 4921-4927.

10 (a) P. S. E. Yeo and M. F. Ng, Chem. Mater., 2015, 27, 58785885; (b) J. C. Knight, S. Therese and A. Manthiram, ACS Appl. Mater. Interfaces, 2015, 7, 22953-22961; (c) C. B. Bucur, T. Gregory, A. G. Oliver and J. Muldoon, J. Phys. Chem. Lett., 2015, 6, 3578-3591.
11 L. H. Jin, Y. Fang, L. Shang, Y. Liu, J. Li, L. Wang, P. Hu and S. J. Dong, Chem. Commun., 2013, 49, 243-245.

12 (a) L. H. Zhang and S. J. Dong, Anal. Chem., 2006, 78, 51195123; (b) L. Wang, C. Y. Yang and W. H. Tan, Nano Lett., 2005, 5, 37-43.

13 (a) H. Zhang, Y. L. Zhai and S. J. Dong, Talanta, 2014, 129, 139-142; (b) F. Montilla, I. Pastor, C. R. Mateo, E. Morallon and R. Mallavia, J. Phys. Chem. B, 2006, 110, 5914-5919.

14 M. Jayalakshmi and F. Scholz, J. Power Sources, 2000, 91, 217-223.

15 L. Deng, F. Wang, H. J. Chen, L. Shang, L. Wang, T. Wang and S. J. Dong, Biosens. Bioelectron., 2008, 24, 329-333.

16 (a) A. Le Goff, M. Holzinger and S. Cosnier, Cell. Mol. Life Sci., 2015, 72, 941-952; (b) J. Gooding and W. R. Yang, Actual. Chim., 2008, 320, 85-89; (c) P. Pinyou, A. Ruff, S. Poller, S. Ma, R. Ludwig and W. Schuhmann, Chem.-Eur. J., 2016, 22, 5319-5326; (d) D. Faggion Junior, R. Haddad, F. Giroud, M. Holzinger, C. E. Maduro de Campos, J. J. Acuna, J. B. Domingos and S. Cosnier, Nanoscale, 2016, 8, 10433-10440; (e) D. P. Hickey, R. C. Reid, R. D. Milton and S. D. Minteer, Biosens. Bioelectron., 2016, 77, 26-31. 